E. I. du Pont de Nemours \& Co. Explosives Department Wlimington 98, Delaware
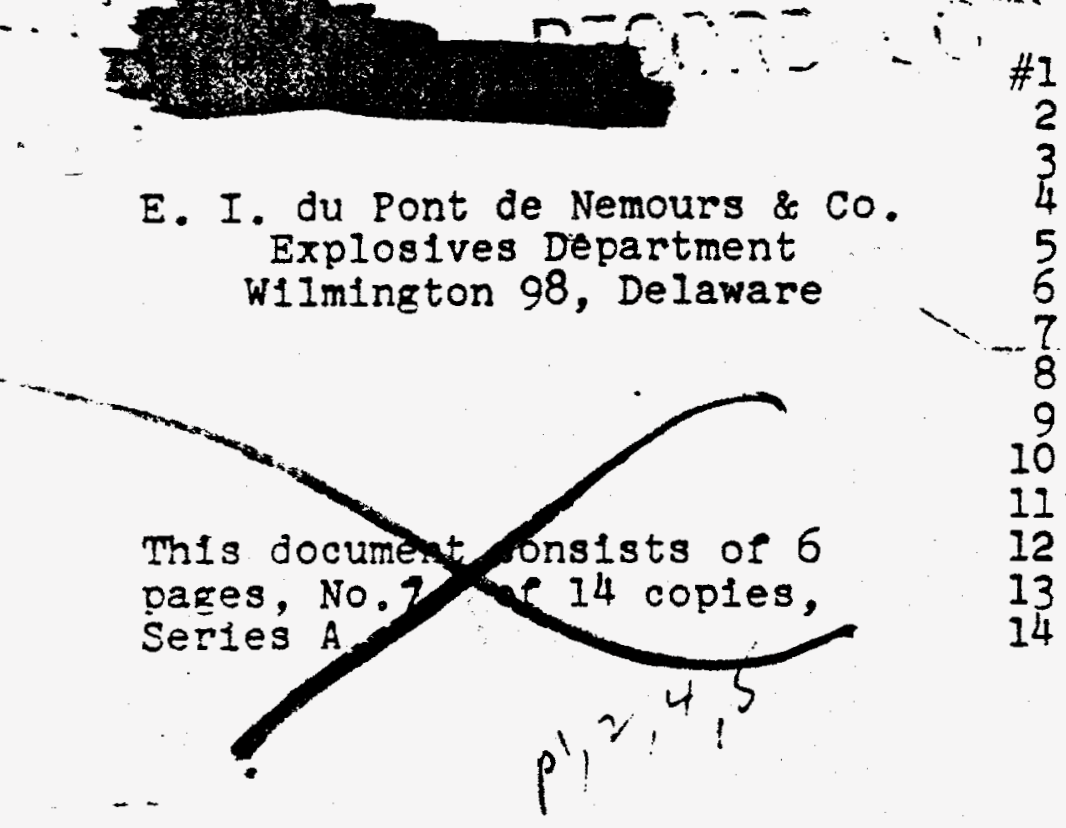

- L. Squires - H. Worthington

2 - J. C. Woodhouse

3 - D. F. Babcock

4 - K. G. Jones - W. J. O'Leäry

5 - A. Pocalyko - G. W. Beckman

6 - N. F. Spraggins - R. E. P1sher

7. "H" Elle.

8 - H. C. Vernon - E. M. Mahla - ERL

9 - I. M. Arnett - ANL

10 - M. H. WahI - P. H. Permar - SRI

11 - C. C. McBride - C. D. Smith - SRL

12 - V. I. Montenjohl - B.W.Dunnington

13 - R. T. Huntoon - SRI

14 - "ST" F1le

NEMCRANDUM TO FILE

IRC: GEORGE W. BECKXAN/S

TRIP REPORT

December 1, 1953

\title{
BATTELLE MEMORIAL INSTITUTE
}

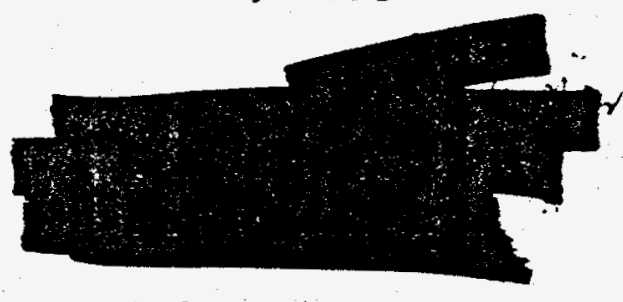

NOVEMBER 1953

\section{SYMAPYYY}

I. The new hot pressing die successfuliy bonded a 3 " $x$ 5-1/2" composite of nickel plated uranium and aluminum.

2. A die for step pressing has been designed and is now in process of fabrication. It w11I be finished by mid-December.

三. Copper and magnes1um additions to the Alsi bath lower the dipping temperature but increase the formation of intermetalilc compound with assoclate loss of duct1lity.

Ootimum dipping rate for continuous AIS1 coatings has been established at

2. The successful extrusion of aluminum over a $1 / 4$ inch diameter Ylindrical core indicates the possibilities of this method.

5. 7-1/2\% $\mathrm{zrU}$ is non-sensitive to oxygen content under crevice corrosion test conditions in bolling demineralized water.

T CONTAIN

OONTROLLEO

$\therefore \because$ Y ORMATION

J

is
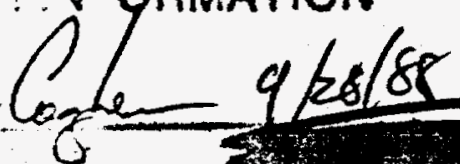

a.

DEC!ASS:F:ED

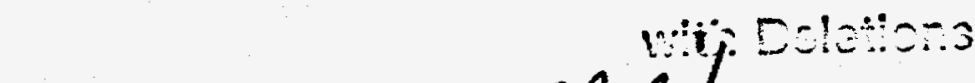




\section{DISCLAIMER}

This report was prepared as an account of work sponsored by an agency of the United States Government. Neither the United States Government nor any agency thereof, nor any of their employees, make any warranty, express or implied, or assumes any legal liability or responsibility for the accuracy, completeness, or usefulness of any information, apparatus, product, or process disclosed, or represents that its use would not infringe privately owned rights. Reference herein to any specific commercial product, process, or service by trade name, trademark, manufacturer, or otherwise does not necessarily constitute or imply its endorsement, recommendation, or favoring by the United States Government or any agency thereof. The views and opinions of authors expressed herein do not necessarily state or reflect those of the United States Government or any agency thereof. 


\section{DISCLAIMER}

Portions of this document may be illegible in electronic image products. Images are produced from the best available original document. 
6. A method has been developed by which progressive deterioration of bond layer in bolling water can be non-destmuctively followed by resistivity measurements.

Preliminary results from using this technique bear out previous indings that the copper bond is not as corrosion resistant as nickel or AIS1.

7. Two non-destructive methods have been developed by which thickness of electroplated nickel on uranium can be measured.

DISCUSSION

Fressure Bonding

Scale-up of pressure clad samples from $I^{\prime \prime} \times 1 "$ to $3^{\prime \prime} \times 5-1 / 2$ " has been successfully accomplished using the picture frame technique. Core thickness was $0.175^{\prime \prime}$, cover plates $0.032^{\prime \prime}$. Cores were electroplated with nickel ta a thickness of $0.0003^{\prime \prime}$. Pressing conditions were psi at for wall load. A partial load of approximateiy 1,000 psi-was applied throughout the heating agcle for about 15 minutes to cisplace entrapped air between the bonding surfaces.

The resulting bonds were excellent in that they could not be pulled apart without tearing the aluminum cover plates. Reduction of oack and core were measured by hand micrometer on samples pressed without nickel barrier layer to facilitate the post press stripping operazion. No reduction of the core could be measured in this manner. The cover plates were plastically deformed 0.004 " per side, or approximately 12\%. More scale-up work is contemplated to verify these results.

Work leading to a better understanding of the corrosion mechanism has been continued. It has been observed that all samples pressure bonced with barrier layers of $\mathrm{N} 1, \mathrm{Cu}, \mathrm{N} 1$ and $\mathrm{Cu}$, or AlS1 falled in corrosion tests by separation of clad and core. Current effort is towaros determining if the corrosion behavior of these systems is caused by different rates of attack or by a difference in length cf incubation period before attack begins. Should the rate of $2 t$ tack be shown to be the same, the cholce of nickel over copper as a bannier layer may not be a valid one in ilght of the superior borisig characteristics of the latter. Metallographic evaluation of corrosion specimens is expected by mid-December. 
The pressure bonding group is also concerned with measuring tensile strength of U-N1-AI bonds. The purpose of this work is to establish the minimum and optimum pressing conditions with respect to tensile strength. Earlier attempts with the pressing of two aluminum rods ( $1 / 4$ inch diameter) and an intermediate wafer of nickel plated uranium were unsuccessful due to local upsetting of the softer aluminum which fammed the die. This difflculty wil. be met by using uranium rods and an aluminum wafer. In addition, a new die has been completed. It is only one-half as long as 1 ts predecessor and it is tapered to aid in retraction of the specimen. Tensile testing of bonds is scheduled after the corrosion evaluation is completed.

Three samples from National Research Corporation were submitted for evaluation at BMI. They were coated with approximately 0.0007 " of chromium by a vapor deposition technique. BMI w111 clad the samples with aluminum by hot pressing and corrosion test the bonded composites. Chemical analysis and thickmess measurements of the coating will also be undertaken.

A sten nressing program has recentiy been initiated at BMI. This project is intended to supplement the work being done at the plant. To date a die has been designed and is currentiy being fabricated. The female part of the die is a one plece channel 34" long, heated its entire length by Cal-rod units. The ram is $4^{\prime \prime}$ long and 1 s formed so as to exert a side pressure to prevent seizing in the die. It is estimated that the die will be finished by mid-December.

\section{Rol Cladding}

The scale-up of roll clad samples to 3 " $\times 18$ " is underway. Three cores have been nlckel plated and three picture frames are ready for rolling as soon as a minor repair has been made to the rolling mill. BMI will use an uncovered steel frame outside the aluminum plcture frame for edge and end restraint.

A series of tests on 2 " $\times 3$ " samples are projected for the study of a post anneal on bond strength.

When extruded sheath is avallable it is intended to study end problems.

\section{AI-S1 Dipped Coatings}

The remaining objective of the dipped coating program is that of finding an addition agent for the bath which will materialiy reduce intermetallic compound formation with an associated increase in coatIng ductility. This can be accomplished by reducing either the rate or extent of diffusion by addition agents which lower the bath temperature or form effective diffusior barriers. 


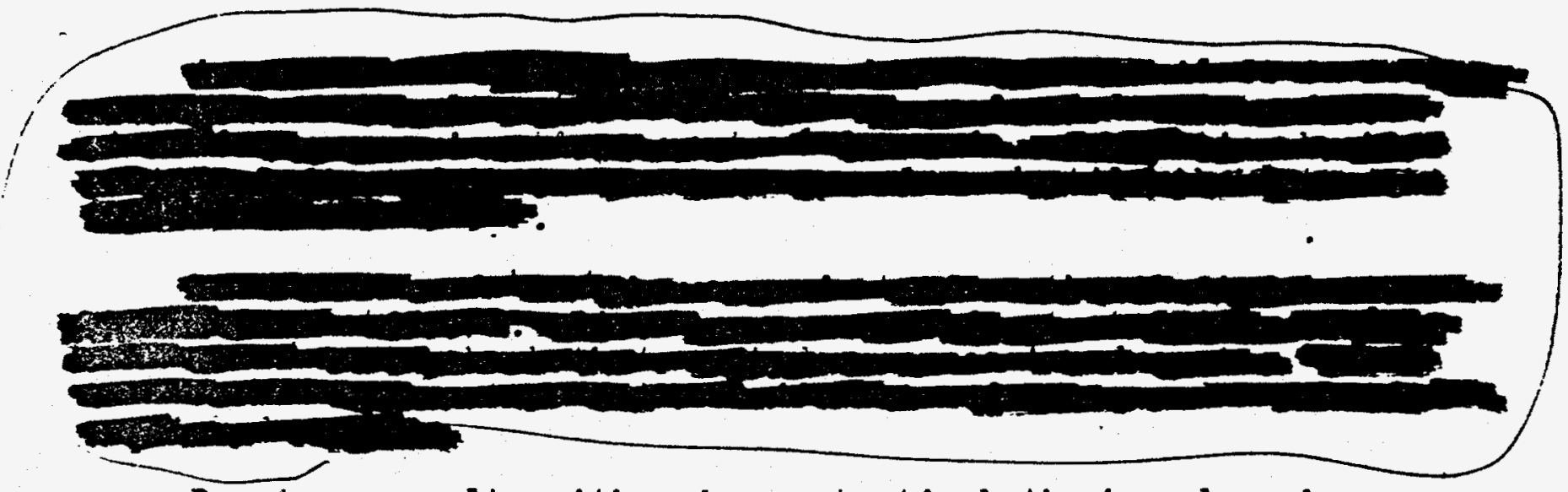

Previous results with a hypoeutect1c bath showed an increase in intermetali1c compound formation. It was also observed that the eutectic bath produced a structure containing primary aluminum dendrites. In an effort to decrease the intermetallic compound formation, and at the same time reduce the primary aluminum dendrites found in the coatings from the eutectic bath, a 14\% hypereutectic bath was tried. It was observed that. the quantity of intermetali1c sompound was approximately equal to that formed in an eutectic bath. Furthermore, the structure stili contains approximately the same volume of primary aluminum dendrites.

\section{DIPPING RATE AND CONTINUITY OF COATING}

D1pping Rate In. $/$ Sec.

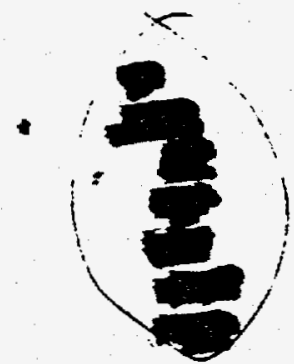

$\frac{\text { Number of Samples }}{\text { Completely }} \begin{gathered}\text { Incompletely } \\ \text { coated }\end{gathered}$

$\begin{array}{ll}2 & 0 \\ 2 & 0 \\ 9 & 0 \\ 1 & 2 \\ 1 & 1 \\ 0 & 2 \\ 0 & 2\end{array}$

It is also reported that oven drying prior to dipping is not oritical. Satisfactory results were obtained with slow dipping at $S$ without the drying operation: 
Early attempts to extmude aluminum over a cylindrical core rere unsuccessful. Radial forces in the upset aluminum billet caused seizing of the core. subjecting it to tensile stresses above its ultimate strength. Recent experiments with a protective steel mandrel between core and billet have made extrusion possible. While the resuits to date are prel1minary in nature, they do indicate that the process is reasible.

A11 tests have been mun with a plat race die at at an extmusion rate of $3-1 / 2^{\prime \prime} / \mathrm{mln}$. Cores are $1 / 4^{\prime \prime}$ diameter nIckel plated steel or uranium. Results are evaluated by X-ray inspection, metallography and peeling tests for bond strength.

-

To date, $1 / 16^{\prime \prime}$ sheathing has been uniformly bonded to nickel plated uranium cores, and $a$ 0.030" zoating has been applied to nickel plated steel cores. An attempt to cover urantum with a $0.030^{\prime \prime}$ sheath was unsuccessful due to bending of the uranium, which is not as strong as steel at?

Samples have been successfully bonded on front and back respectiveig but never on the same sample. A study on influence of

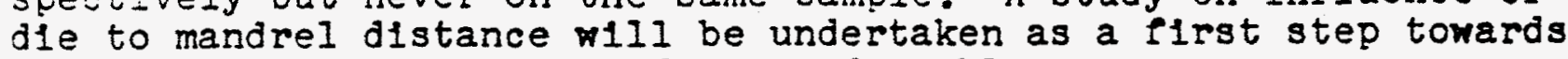
solving both the bending and the end problems.

Visual examination of $X$-rays of the bonded composite indicate a uniformly coated sample.-A stripping test performed on a $3 / 16^{\prime \prime}$ thick clad sample tore pleces of aluminum indicating a good bond. Metallography shows diffusion between pack components.

\section{Corrosion}

Additional corrosion information is avallable on the 5\% $\mathrm{Zr}$ alloy. To reconfirm previous results a number of tests have been mun to pin down the $\mathrm{H}_{2}$ to $\mathrm{O}_{2}$ concentration effect with the $5 \%$ alloy. In an environment of 25:1 rat1o the alloy has held up for 3 weeks and is

- stili okay. A isimilar sample exposed to $35: 1$ ratio environment falied in one week.

The $5 \% \mathrm{Zr}$ alloy was known from prevlous experlence to be $\mathrm{O}_{2}$ sensitive in crevice corrosion attack. The 10\% alloy, however, proved to be non-sensitive in this respect. It has now been discovered by testing samples in half percent increments from 5 to $10 \%$ that the 7-1/2\% alioy is not sensitive to oxygen content. This latter alloy has successfully withstood 5 weeks in $\mathrm{H}$ a saturated water and is still in good condition. (Note that one week or less was surficient to cause sensitive materials to fall.) 
The corrosion group has also been working toward the development of a non-destmuctive method by which crevice corrosion attack could be followed. A resistance measurement seems to show good promise. A serles of tests were run on $1^{\prime \prime}$ square sandwiches bonded w1th AlS1, $\mathrm{NI}$, and $\mathrm{Cu}$ respectively. A plot of resistance versus time shows a parabolic function. In the inftial tests the one AIS1 sample measured falled in 24 hours; $C u$ falled in 96 hours, and the resistance of the $\mathrm{N} 1$ continued unchanged at 96 hours. The premature fallure of AlS1 is considered to be the result of a poor bonding Job: The uneven coating of AlS1 obviously did not permit a continuous bond. New samples will be measured. Calibration will be effected by testing samples with varying contact areas of aluminum, as well as by metallographic evaluation of the standard sample.

\section{Non-Destructive Testing}

Two non-destructive methods for measuring nickel plating thickness have been developed at BMI, an X-ray and an eddy current technique respectively. Both methods have been shown to be feasible and calibration and determination of sensitivity is now underway. The application of $\mathrm{X}$-rays and eddy current techniques to measuring sheath thickness is also being surveyed. 